\title{
Welding materials used to increase service life of agricultural machinery processing soil
}

\author{
Petr Hrabě $^{*}$, Viktor Koláŕr ${ }^{1}$ Abraham Kabutey ${ }^{2}$, Aleš Sedláček ${ }^{2}$ \\ ${ }^{1}$ Czech University of Life Sciences Prague, Faculty of Engineering, Department of Material Science \\ and Manufacturing Technology, Kamýcká 129, Praha 6 - Suchdol, Czech Republic \\ ${ }^{2}$ Czech University of Life Sciences Prague, Faculty of Engineering, Department of Mechanical \\ Engineering, Kamýcká 129, Praha 6 - Suchdol, Czech Republic
}

\begin{abstract}
Intensive abrasive wear occurs in soil-treatment machines. This article is focused on increasing the service life of ploughs by the welding material. The welding material is applied at a $45^{\circ}$ angle to the tool. This material is abrasive wear resistant. The welding material was applied parallel to the head of ploughshares with spacing of $60 \mathrm{~mm}$. Carbide materials were used (SK 258 TiC-O, SK 900-O, SK A43-O, SK 299O, SK A45-O, OK TUBRODUR 15.82, SK 258 TiC-O). The tested ploughshare variants were wearing the same when were used the welding material and the standard.
\end{abstract}

Keywords: abrasive wear, ploughshare, statistics

\section{Introduction}

Intensive abrasive wear occurs in soil-treatment machines. Abrasive wear is characterized by a reduction in tool volume and a change his shape that gradually reduces the work quality of the tool. The tool must be replaced after a certain limit has been exceeded. Renovation is one of the possible ways to keep the tool in a workable condition $[1,2]$.

The properties of the functional surface of tools and components can be effectively changed. Classical methods include welding, which makes it possible to successfully reduce materials and economic costs [1]. The success of the renovation was proven by ploughs [2].

The ploughshare is one of the most stressed parts of the plough and is subject to considerable demands. The ploughshare must meet relatively high strength requirements (especially toughness) and high wear resistance due to soil abrasive. The main cause of excessive wear of ploughshares are the hard particles contained in the soil (siliceous sand, stones). The size, shape and hardness of soil particles, climatic conditions, soil compaction and soil moisture are the main factors of abrasion intensity [3].

Abrasive wear can be reduced to an acceptable degree by appropriate technology and by selecting material to produce the entire tool or its part in greatest wear. The latest research attempts to find and apply such techniques in the production of ploughshares to reduce the friction between the tool and the soil. It would increase the service life of the most stressed parts and reduce soil resistance, which would save fuel [1-5].

\footnotetext{
* Corresponding author: hrabe@tf.czu.cz

Reviewers: Daniela Kalincová, Janusz Zarajczyk
} 
Increasing of the service life of ploughshares has become increasingly topical in recent years. Creating better soil technology would ensure a significant improvement in the economy of the operation of these facilities. Potential savings from friction and wear reduction through improved tribology of agricultural tools would amount to almost $\$ 337$ million per year [6].

A significant problem is the change in shape geometry, which also changes the vertical force response, which effects the deepening of the plough from the furrow. Decrease of the quality of the plough, reduction of the ability of the processing of plant residues etc. are negative consequences [7].

In the field of soil technology, it is possible to reduce the energy intensity as well as to increase the life of the tools by optimizing the material design solution. The wear of the tool can be reduced not only by used material, which is characterized by increased resistance to wear but also by the design, i.e. by shaping using shapes or design solutions combining different materials that effectively solve the problem. Welding is one way to create a new functional surface. Changing geometry, increasing the cross-section including energy intensity are a potential negative $[8,12]$.

The aim of this research is to evaluate the experiment of selected welding materials in the field test of wear of ploughshares.

\section{Materials and methods}

A field test in 136 hectares of field was performed for the experiment with a deep plough $(25-30 \mathrm{~cm})$ of a seven-shares Kverneland PB 100 plough. A welding machine with continuously served wire by ESAB with the LAF 635 DC source and the A2-A6 Process Controller was used for the welding of selected welding materials to ploughshares. The welding parameters for all materials are in Tab. 2. The welding parameters were chosen so that the width and height of the weld were the same for all types of welding materials. Two sets (14 shares) were welded due to shorter downtime during demounting, statistical evaluation and re-assembly of ploughshares. The mounds were placed on a share with spacing $60 \mathrm{~mm}$ and at an angle of $45^{\circ}$ to the share edge. Layout of shares with the welding material was the same for both sets. The welding materials for the experiment were selected in the following order from the tractor (Table 1). Table 1 shows a guiding chemical composition of the used welding electrodes too.

Table 1. Welding materials used for the experiment and their guiding chemical composition

\begin{tabular}{|c|l|l|}
\hline Order & \multicolumn{1}{|c|}{ Welding material } & \multicolumn{1}{|c|}{ Guiding chemical composition [wt\%] } \\
\hline 1 & SK 258 TiC-O & C-1.8; Mn-0.9; $\mathrm{Si}-0.2 ; \mathrm{Cr}-6.1 ; \mathrm{Mo}-1.4 ;$ Ti-5.5; Fe-base \\
\hline 2 & SK 900-O & C-2.9; Mn-0.5; Si-0.4; W-42; Cr-5.8; Fe-base \\
\hline 3 & SK A43-O & C-5.6; Mn-0.2; Si-1.3; Nb-6.7; Cr-20.2; Fe-base \\
\hline 4 & SK 299-O & $\begin{array}{l}\text { C-4.9; Mn-0.3; Si-1.0; Cr-11.30; Nb-6.8; V-6.0; B-0.7; } \\
\text { Fe-base }\end{array}$ \\
\hline 5 & SK A45-O & $\begin{array}{l}\text { C-5.3; Mn-0.2; Si-0.7; Nb-6.0; Cr-21; V-0.8; Mo-6.3; W- } \\
1.9 ; \text { Fe-base }\end{array}$ \\
\hline 6 & OK TUBRODUR 15.82 & $\begin{array}{l}\text { C-5.0; Mn-0.9; Si-0.9; Nb-5.4; Cr-19; V-1.2; Mo-1.1; W- } \\
1.2 ; \text { Fe-base }\end{array}$ \\
\hline 7 & SK 258 TiC-O & C-1.8; Mn-0.9; Si-0.2; Cr-6.1; Mo-1.4; Ti-5.5; Fe-base \\
\hline
\end{tabular}


Table 2. Welding parameters for all materials

\begin{tabular}{|l|c|}
\hline Current $(\mathrm{A})$ & 250 \\
\hline Voltage $(\mathrm{V})$ & 25 \\
\hline Speed $(\mathrm{cm} / \mathrm{min})$ & 25 \\
\hline Energy $\left(\mathrm{kJ} / \mathrm{cm}^{3}\right)$ & 13 \\
\hline
\end{tabular}

Dimensional and mass analysis were used to evaluate the service life of the ploughshares. The individual dimensions and weights of welded and standard ploughshares were measured after every seventeen hectares during the field test. Dimension A was measured at the tip of the share, dimensions B, C, D through screw holes and E in the back of the share (Fig. 1). A millimeter tape measure was used to measure individual dimensions. The weight of the shares was measured on a Portable Electronic Scale weight with accuracy to one thousandth of a kilogram.

The measured data were evaluated in STATISTICA program by using ANOVA F-test statistical method. Hypothesis $\mathrm{H} 0$ shows that there is no statistically significant difference ( $>0.05$ ) between the test data. Hypothesis $\mathrm{H} 1$ denies the $\mathrm{H} 0$ hypothesis and states that there is a statistically significant difference between the test data $(\mathrm{p}<0.05)$.

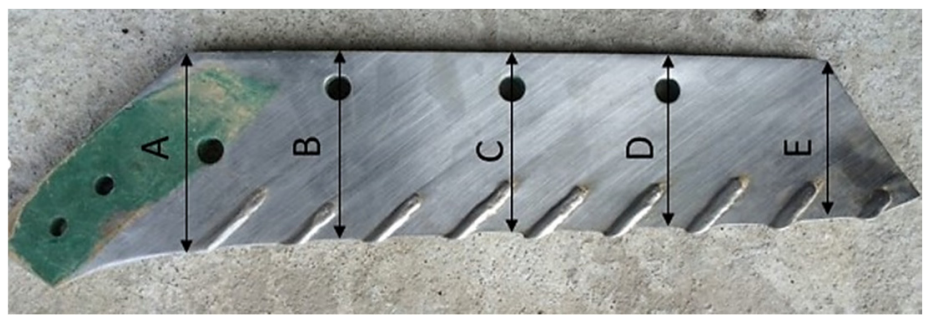

Fig. 1. Methodology of measuring individual dimensions of ploughshares

\section{Results and discussion}

From the point of view of statistical testing of the influence of different welding materials, it can be stated that they are statistically homogeneous groups, i.e. there is no difference between variants of the experiment, i.e. different welding materials and standards (Fig. 2). The $\mathrm{H}_{0}$ hypothesis was confirmed, i.e. there was no difference in significance level of 0.05 between the individual tested variants.

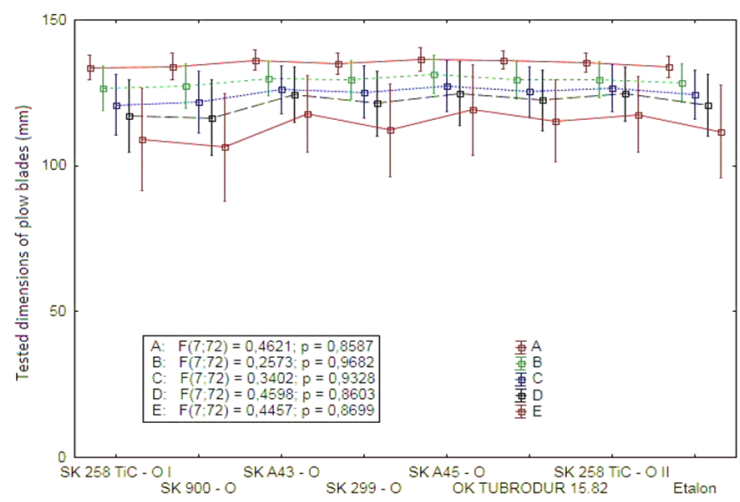

Fig. 2. Statistical testing of the influence of the different welding materials 
From the point of view of statistical testing of uniformity of wear of the ploughshare over whole length of the share, i.e. changes in the geometric shape, it can be stated that it is statistically inhomogeneous groups, i.e. there is the difference between the tested parameters (measured points A, B, C, D and E).

The $\mathrm{H}_{0}$ hypothesis was not confirmed, i.e. there was a difference in the significance level of 0.05 between the individual tested variants of the experiment (SK 258 TiC-O I, SK 900O, SK A43-0, SK 299-O, OK TUBRODUR 15.82, SK 258 TiC-O II and standard). It follows from the above that the ploughshare is unevenly worn. This statistical conclusion of the measured data is supported by the results shown in Fig. 3.

This conclusion was not confirmed for SK A45-O, where $\mathrm{p}=0.0848$. The $\mathrm{H}_{0}$ hypothesis was not confirmed for this weld, i.e. there was no difference in significance level of 0.05 between the individual measured points A to E. Statistically difference was not found between the standard and the various welding materials.

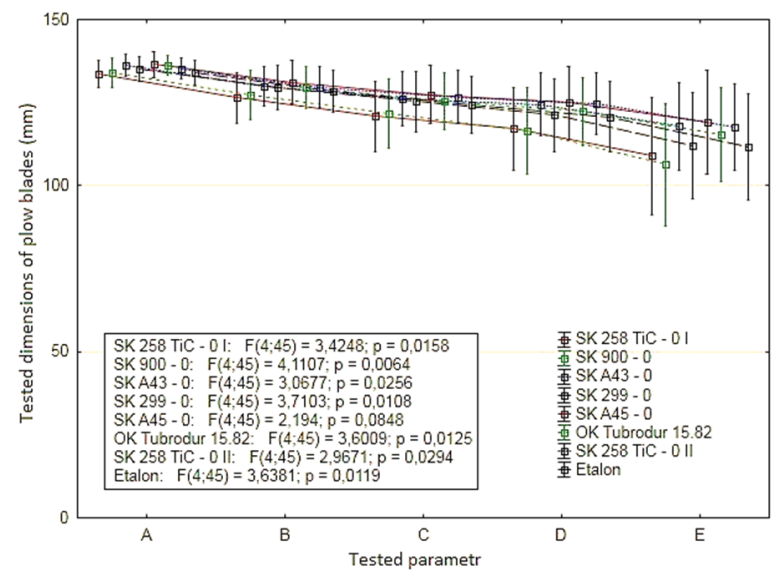

Fig. 3. Statistical testing of uniformity of wear of the ploughshares

From the point of view of statistical testing of weight loss in individual variants it can be stated that these are statistically homogeneous groups, i.e. there is no difference between tested parameters of experimental variants.

The $\mathrm{H}_{0}$ hypothesis was confirmed, i.e. there was no difference in the significance level of 0.05 between the individual tested variants of experiment (SK 258 TiC-O I, SK 900-O, SK A43-O, SK 299-O, OK TUBRODUR 15.82, SK 258 TiC -OII and standard) $p=0.1628$ (Fig. 4). It follows from the above that the ploughshare is worn identically with the use of welding materials and standards.

The dimensional loss of welded shares was only $0.41 \%$ less than in the standards at the end of the experiment. Determination coefficient is higher for standards $\left(\mathrm{R}^{2}=0.9765\right)$ than for welded shares $\left(\mathrm{R}^{2}=0.9666\right)$.

The decisive factor in increasing the service life of the welded share relative to the standard is the dimension measured on the heel of share (in our case dimension E). The dimensional loss was $17.6 \%$ lower for the SK A43-O welding material than for the standard. It is possible to say that the service life of the welded share has increased relative to the standard. The dimensional loss was $1.1 \%$ lower for the SK A45-O than for the standard and for OK TUBRODUR 15.82 3.7\% lower than for standard. The dimensional loss was $7.8 \%$ higher for SK 900-O than for standard and $7.9 \%$ higher for SK 258 TiC-O than for standard. Welded shares have $5.97 \%$ higher weight loss than standards. Determination coefficient is higher for standards $\left(\mathrm{R}^{2}=0.9912\right)$ than for welded shares $\left(\mathrm{R}^{2}=0.9886\right)$. 


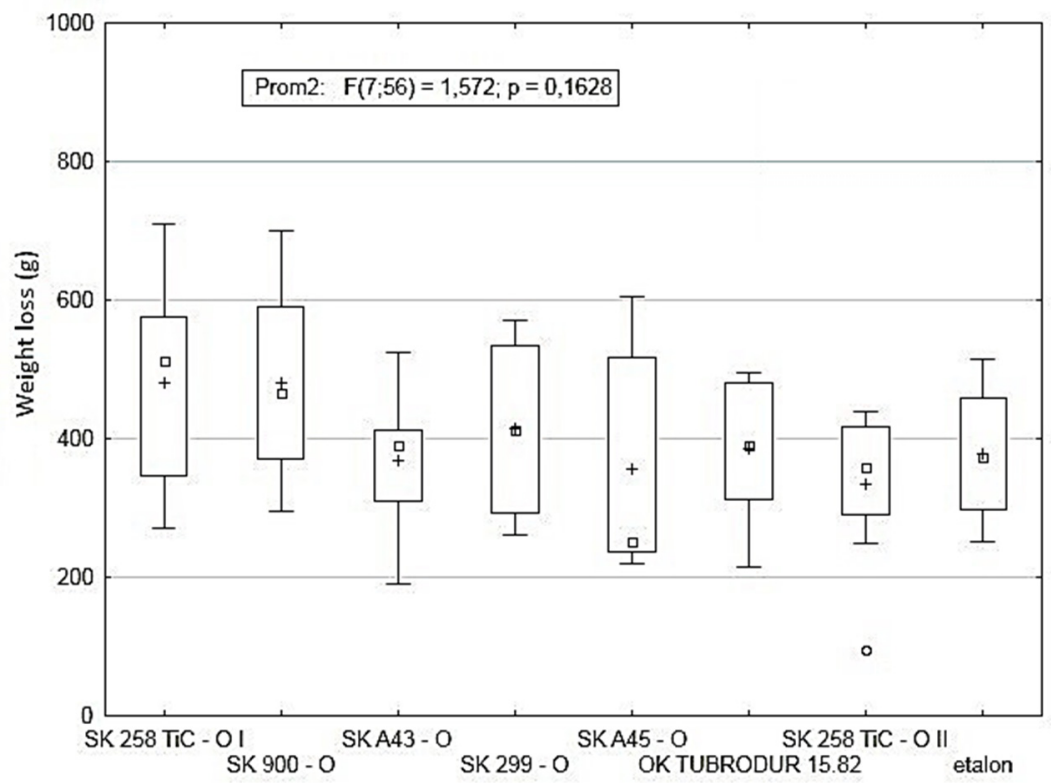

Fig. 4. Statistical testing of weight loss

The results of the experiment have confirmed the need for material and design research in a soil processing area $[9,11]$.

Technique of soil processing as a plough can be mentioned as a sample in which wear causes fuel surge, a fall in work efficiency etc. [9].

The experiment of ploughshares wear has shown lower fuel consumption and higher ploughing efficiency in shares with hard welding material compared to standards. The results of the research proved an increase in the service life of the ploughshare with the welding material OK TUBRODUR 15.82. The wear was $16.9 \%$ lower than for the standard after 87 ha of ploughing [10].

The weight loss was $130.45 \pm 22.28 \mathrm{~g} / \mathrm{ha}$ in dry soil and $98.06 \pm 12.85 \mathrm{~g} / \mathrm{ha}$ in wet soil. Ploughshares are worn at an average of 90 to $210 \mathrm{~g} / \mathrm{ha}$ [6].

\section{Conclusions}

The research was focused at increasing the service life of ploughshares. An obliquely applied welding technique was used due to the high cost of wearable parts. Dimensional and mass analysis were used to evaluate the service life of the ploughshares. These conclusions can be deduced from the results of the research:

1. Changes in share height, bottom edge length at share tip, share front length and share weight clearly did not show added value by welding. The course of partial dependencies was similar with minimal differences. By statistically comparing the mean values of weight, a statistically significant difference was not found between the tested variants.

2. Efficiency of ploughing is from the point of view of a practical user the most important (i.e. speed, fuel consumption, quality, etc.). Efficiency of ploughing has 
confirmed the efficiency of the creation of a "tooth share" due to gradual wear. These conclusions can be determined on the basis of the cutting conditions of the "tooth share".

3. It is possible to create an abrasion-resistant surface, but also to use different geometrical arrangement of the welding layer. The aim of this arrangement is to follow the course of processed soil. The ploughshare with this functional surface is wearing unevenly during ploughing.

4. The experiment has confirmed the effectiveness of ploughing. The "tooth share" has always kept a distinctive self-sharpening effect. This effect greatly improves the sinking of the plough into the soil especially in the dry conditions.

\section{References}

1. S. Petrásek, M. Müller, Setting of angle of soil flow on ploughshare at traditional processing of soil. Manufacturing Technology, vol. 3, 407-412 (2014)

2. P. Čičo, M. Kotus, M. Vysočanská, Renovation of sugar beet harvesters - prolongation of service life. Listy cukrovarnické a řepařské, vol. 9-10, 280-283 (2012)

3. M. Müller, P. Hrabě, Overlay materials used for increasing lifetime of machine parts working under conditions of intensive abrasion. Research in Agricultural Engineering, vol. 59, 16-22 (2013)

4. M. Müller, P. Novák, P. Hrabě, Inovace materiálově konstrukčních řešení plužní čepele v oblasti konvenčního zpracování půdy při pěstování cukrové řepy. Listy cukrovarnické a řepařské, vol. 3, 94-99 (2014)

5. M. Müller, R. Chotěborský, P. Hrabě, Aplikace návarového materiálu na nástroje zpracovávajíci pi̊du za účelem zvýšení jejich odolnosti vioči abrazivnímu opotřebení, Listy cukrovarnické a řepařské, vol. 9-10, 279-283 (2015)

6. Y. Bayhan, Reduction of wear via hardfacing of chisel ploughshare. Tribology International, vol. 39, 570-574 (2006)

7. V. Legát, V. Jurča, Z. Aleš, Contribution to plough shares and chisels useful life optimization. Scientia Agriculturae Bohemica, vol. 42, 73-78 (2011)

8. M. Müller, P. Novák, R. Chotěborský, P. Hrabě, Efektivní zvýšení životnosti plužní čepele. Mechanizace zemědělství, vol. 62, 68-70 (2012)

9. A. Natsis, G. Petropoulos, C. Pandazaras, Influence of local soil conditions on mouldboard ploughshare abrasive wear. Tribology International, vol. 41, 151-157 (2008)

10. Z. Horvat, D. Filipovi, S. Kostic, R. Emert, Reduction of mouldboard plough share wear by a combination tech $\neg$ nique of hardfacing. Tribology International, vol. 41, 778-782 (2008)

11. P. Doubek, J. Filípek, Abrasive and erosive wear of technical materials. Acta Universitatis Agriculturae et Silviculturae Mendelianae Brunensis, vol. 59, 13-21 (2011)

12. D. Kalincová, M. Ťavodová, V. Luptáčiková, Application of the weld deposits on function surfaces of the forest machines components. Manufacturing Technology, vol. 18, No. 3, 400-405 (2018) 